\title{
History and Typology of the Instrumental Case (Based on the Comparative Study of the Literary Documents in Turkic Languages)
}

\author{
Aynur Gadimaliyeva \\ Assistant Professor, Azerbaijan State University of Economics, Department of Azerbaijani Language \\ aynur.gadimaliyeva@asue.edu.az
}

Abstract

\begin{abstract}
This article touches upon the research, which employing comparative historical approach has been carried on about the instrument-togetherness (instrumental) case - the seventh case of noun, which is used in most of the Turkic languages, but has been removed from grammar books after becoming archaic in the Azerbaijani literary language. This case, having kept its place in the history of development of the Azerbaijani language is still evident in stabilised state within some lexical units through the suffixes - In, in, which are the morphological indicators of the instrumental case. As postpositions birlə, bilə, ilə, la, -la denote togetherness, this has caused the expulsion of the instrumental case from among the case paradigm. This article uses the samples selected from the XV century literary works, analyzes the morphological indicators of this ancient case, and compares them to the sources in other Turkic languages.
\end{abstract}

Keywords: Azerbaijani-Turkic language, noun, instrument-togetherness (instrumental) case

\section{Introduction}

The case category of noun has been stabilised after going through a certain path of historical development. As such, as the grammatical structure of the language became stabilised, the case system has also evolved and the process of attachment of the case indicators to individual cases has gained momentum. This process is characteristic not only for the Azerbaijani language, but for all the other languages as well.

It has been established that the case category, having specific morphologic indicators serves to establish grammatical connections between words within a sentence. Taking into account the important role of the case suffixes in the formation of a sentence, M. Huseynzade notes that " ... case is an issue within grammar pertaining both morphology and syntax... Therefore, when speaking about the case category of noun, in addition to the morphological features it is essential to also touch upon some of their syntactic characteristics as well" (1983, p. 50). In Turkic languages, including the Azerbaijani language, the grammatical case has always been in the structural model of root of word + case suffix.

According to Y. Seyidov, "The current case system of the Azerbaijani language was already formed in the XIV century Azerbaijani-Turkic language. Even though at later periods there has happened certain refinements and stabilisations in the grammatical meanings of the cases, the system itself has remained basically unaltered" (2000, p. 233). However, varying explanations can be found in Azerbaijani linguistics in regards to the names, number and ordering of the cases. $M$. Huseynzade provides us with information that until 1934, the cases were defined according to the suffixes added to the noun, and consequently, eight cases of noun were proposed (in addition to the current six cases, two more cases were intended - those that would be formed with the postpositions -üçün, -çin, -çün and ilə, -la, -lə). That same year, the names of cases were established in Azerbaijani for the first time, their number became seven, including the instrumental case that was later removed from the grammar books. In 1939, instrumental and genitive cases were dropped out, but in 1944 the number of cases was finally fixed at six, after restoring the genitive case (Asker, 2003, p. 192).

We can observe a similar scene in Turkic literature in regards to the number of cases. A. von Gabain writes that there are nine cases of noun (1998, p. 39). Studying the the language of the ancient Turkic monuments A. Shukurlu also talks about the existence of 9 cases of noun. (1993, p. 91). While Majdut Mansuroglu writes that there exists 9 cases of noun in the Garakhanli Turkic dialect (1998, pp. 151-155), A. Dilaçar stresses that in many such numberings the nominative case has not been taken into account, and consequently, there would be 10 cases including the nominative case (1995, pp. 60-65). In the works of A. Rajabli, M. Novruzov, Y. Mammadov it is noted that there exists 8 cases of noun (Rajabli, 2002, p. 91; Novruzov, 1987, p. 27; Mammadov, 1979, p. 36). A. M. Sherbak on the other hand, talks about 7 cases of noun in the XXIII century texts from East Turkestan (Щербак, 1961, pp. 76-92). R. Asker, extensively touching upon these classifications 
that were proposed before himself, stresses that the names of cases are partially concurring in the works of these authors, and thus he sees it fit to bring the number of cases to 7 by adding the instrumental case (2003, pp. 194-197).

Such diversity of opinions and confusion has led some Turkologist researchers to wrongly propose the argument that current contents of the case paradigm in the Turkic languages, including the Azerbaijan language has been initially formulated based upon the cases in the Russian and European languages. A. Alizade, expressing an opinion on this position, also argues that "in all the grammar books written in the nineteenth century, such as I. Giganov's "Грамматика татарского языка" (1801), M. Ivanov's "Татарская грамматика" (Казань, 1842), M. Kazim-bek's "Обшая грамматика турецко-татарского языка" (Казань, 1846), А. Troyanski's "Краткая татарская грамматика" (Москва, 1860) the case paradigm can be seen to be in the case system of the Russian and European languages. It is true that those same grammar books mention the already archaic instrumental-togetherness case of the noun under various terms. However, this has not achieved a stable position within the case system" (Alizade, 2006, p. 3).

After taking into consideration the arguments already furthered on the issue of the case category, some of which I have sought to reflect as much as possible, we can come to a conclusion that in addition to the existing 6 (nominative, genitive, dative, accusative, locative, ablative) cases it would be appropriate to talk about the seventh case of noun with the addition of the archaic instrumental-togetherness case found, albeit not extensively, when exploring the language of the XV century literary documents.

Being referred to under various terminology in the Turkologist literature, the instrumental case possesses complex characteristics, and may denote togetherness, instrumental, and meditative meanings. The ancient morphological indicator of this case, which creates a grammatical link in sentence between the noun and verb had been the suffix - In, $-i n$. A. M. Sherbak proposes that the instrumental case denoted with - in, -in affixes in the texts from East Turkestan has evolved into a group under adverb in the XI-XIII, and was replaced by bilə, birlə postpositions. In later periods, instrumental case that was formed with -la, -lə affixes had become widespread (Щербак, 1961, pp. 88-89). Y. Mammadov, confirming this fact notes that the instrumental case is used more frequently in Orkhon-Yenisey texts than Uighur texts and "Qutadgu Bilig" (1979, p. 74).

Studying the literary documents of the XV century, we find that the use of the instrumental case formed with -In, -in suffixes is still very rare. This in turn, leads us to observe that in the preceding centuries -In, -in suffixes had already lost their usage in the language by becoming archaic, and the only remaining vestiges were those that became crystallised and left in the structure of some words. In samples where it is found, the instrumental case mainly denotes one of the following: tools or means that perform an action, the process that would occur in certain time units or seasons, the manner and style of execution of an action. For example:

Oxun sözi əgərçi ötər başü canuma (Pashali, 2011, p. 375);

Qürabi-şəb çü düzdü pərrü balın,

Qəfayə saldı hər məşriq cibalın,

Qanat bükdivü qıldı göz qarasın,

Həvadən gözlədi məğrib yuvasın (Nagisoylu, 2011, p. 161);

İnayət qılıcın çünkim quşana (Kishvari, 1984, p. 163);

Qışın saqlamasa sirrini gər yer,

Yazın olmaz idi xoş səbzəyi-tər (Musayeva, 2003, p. 166);

Yarın yer edünürsən duzəxi sən (Kishvari, 1984, p. 180);

avvəlin bir danə dikdi, axərin ol danədən,

Həm dirəxtü şaxü bix, həm gülü xar eylədi (Nagisoylu, 2011, p. 196);

Gül üsnə sağın sünbüli-xoşbu düşünübdür (Pashali, 2011, p. 304);

Otur övrət kibi sağ evdə sağın (Nagisoylu, 2011, p. 183); 
Yüz sürüb andan dögübən dizin (Musayeva, 2003, p. 247);

Musəyi sən sanma, saqın tizü tünd (Kishvari, 1984, p. 244);

Sənsizin boldi mana kuyi-ədəm aramgah,

Necə çəksün bir kişi peyvəstə biaramlıq (ibid, p. 34);

Sənsizin, ey gül, keçər mundaq qışü yazım mənüm (ibid, p. 54);

İrib atasına ansızın oğlan (Musayeva, 2003, p. 211), and etc.

Most of the examples given above have become to fulfill the function of adverb in the contemporary literary language. A. Shukurov expresses his opinion on the "adverbized" words in the instrumental case as following: "It is known that the instrumental case was preserved in the ancient Turkic language until the $X$ century. Presumably, this suffix became gradually archaic after the $X$ century. Additionally, ilo postposition has played an important role in the process of the instrumental case becoming archaic. Therefore, many words that can be found in the literary documents in the form of instrumental case should be treated as "adverbised" words" (Shukurov, 1981, p. 19).

In the ancient Turkic sources instrumental case, although not widespread, does indeed exist. In M. Kashgarli's "Divanu Lûgat-it-Turk" one can find examples such as, "kuş kanatın, ər atın" (Kashgarli, 1985, pp. 34-35); in Yusif Khas Hajib's "Qutadğu Bilig":

okın urdu ödlək,

kinqəşin itər ol kişi öz işi

künün yemədi, kör, tünün yatmadı (Askar, 2003, p. 213)

We can see further examples in Dada Gorgut: Xan tezin Qazan üzərinə gəldi (Kitabi-Dede Gorgut, 1988, p. 18); dizin çəkdi, aydır (Kitabi-Dede Gorgut, 1988, p. 58); and in "Qisseyi-Yusif": fəsih tilin, səhih sözün söylər imdi (Mammadov, 1979, p. 74).

Even though the instrumental case has lost currency in modern literary language, morphological indicator of this case can often be seen in the structure of some the expressions in a crystallised form. For example; it has preserved its existence in expressions such as, için-için ağlamaq, dizin-bizin sürünmək, oğrun-oğrun baxmaq, xisin-xisin gülmək, as well as in words like arxayın, ilkin.

Eventually, birlə, bilə postpositions came to be used in place of the instrumental case after replacing, and then completely supplanting the - In/-in, -la/-lo suffixes. These postpositions themselves have also undergone modifications and have assumed various shapes as a result of further historical developments of the language. Even their parallel usage can be observed in some literary documents: birl $2<$ bil $\theta<$ bilən<ilən<il $<<\mid a<1 \partial<n a n<n ə n$. For example;

Xaki-payin birlə istərmən urum göz rövzənin (Kishvari, 1984, p. 18).

Gögçək ləbindən gər qılur yüzün bilə dəvi günəş (ibid, p. 24).

Birlən, birlə, bilə postpositions are formed from two components; that is from the combination of the word bir, which denotes number, and -lə suffix which forms verb, with the addition of the ancient verbal linkage unit $n$. "Birlən once meant together, in union. However, at the later stages it developed and transformed from independent word to auxiliary, acquired the characteristics of postposition, and started carrying a second meaning in addition to the previous one. In other words, birlən, birlə, bilə postpositions denotes taking two items together, or execution or accompaniment of some work, action with some item. In the second situation, it would fall in the case of noun named "instrumental case" (Mirzazade, 1990, p. 208). 
Instrumental case formed with -lan, -lən suffixes can be seen more often in the literary documents:

Ol gün ki, səninlən içəmən badeyi-gülgün,

Məhşər kimi sərməd bolisi dövlətim ol gün (Kishvari 2010, p. 46),

Mənimlən ta yaman oldun, məni öldürdü qayğular (Kishvari, 1984, p. 25),

Oxilən neçə gün, ey dil, arada gər iraxlığdır (Pashali, 2011, p. 294),

Bir öpüş/ən, ey gözüm, ağzımni şirin et, digəc (ibid, p. 285),

Zülf yüzünlən müqabil olsa, döndər kim, deyər,

Gecə gündüzlən müqabil oluncax novruz olur (ibid, p. 288), etc.

Sometimes, suffixes -dan/-den, -dın/-din which in the XV century literary language was the suffix of ablative case, can denote instrumental case depending on the usage. For example:

Göz qanındin yazmışam mənşuri-hüsnün hər yana (Kishvari, 2010, p. 39),

Adəm ol toprağdin sərmayeyi-can bağladı (ibid, p. 43),

Həstətindin həmçinan kim, var idim, varəm hənuz (ibid, p. 26),

Mən sögüşündən sənin ögməğini fərq etməzəm,

Tanrı sözini ədəbsizlikdir etmək intixab (Pashali, 2011, p. 281),

Nə yüzdən hüsnüni vəsf edə vasif,

Pəri nisbət çü Vasifdən nihansən (Musayeva, 2012, p. 617), etc.

Nouns used as göz qanındin, toprağdin, həstətindin, sögüşündən, yüzdən in the samples do not show the point of departure, but signifies instrumental, meditative meaning.

The evidence of the usage of -dan, -dən suffixes found in the ancient literary documents by Academic M. Shiraliyev reaffirms that the instrumental case had been historically a conventional category of Azerbaijani language (Alizade, 2006, p. 6).

-dan,-dən as a suffix of instrumental case has attracted the attention of Mirza Kazim-bek too, and he cites the following as the examples of the instrumental case in Turkic languages:

Bu hünər bəndən düzəlməz,

Dənizdən ya qurudan gəldiniz? (Казым-Бек, 1846, p. 53)

We can also show the same situation in the contemporary Turkmen language, in regards to the -dan, -dən suffix: sebet üzümden dolu (Туркменско-русский словарь, 1968, р. 278).

Unlike the Azerbaijani language, in some modern Turkic languages the instrumental case, taking its areal of usage into consideration, has been included in the case paradigm. For example, according to $\mathrm{K}$. Musayev in Karaim language instrumental case, formed by -ba, -bə suffixes, is counted as the 7th case of noun. It is relatively younger as a case and has been derived from bila postposition, which is rarely used. According to the author, this new case has also new features: -ba, -bə case suffix is added to personal and indicative pronouns after the genitive case. Within a sentence, it is more associated with bol-, kll-verbs, and semantically it is close to the semantics of the Russian-language tvoritelny (ablative) case (Мycaeв, 1961, p. 158). 
In the case of Shor language, 7 cases of noun are counted, taking into account both the ancient and modern usage of the instrumental case, and the 7th case is named tvoritelniy-instrumentalniy-orudniy and is formed with bila, bile, mila, mile postpositions and -ba, -be, -pe, -ma, -me suffixes (Дыренкова, 1941, p. 45). In Khakas language the 8th case of noun instrumental-togetherness case is used widely with bulan, menen, blan postpositions and their -nan, -neng form, which has evolved into suffix (Донидзе, 1955, p. 145). This case has been added to the case paradigm also in Tofalilar language (Рассадин, 1978, р. 43).

As we can see, in most of the Turkic languages the ancient instrumental case of noun is among the grammatical cases and has preserved its existence in various phonetic versions. Touching upon the grammatical function of this ancient case in the Azerbaijani language, which is of enabling the formation of connection between the words, A. Alizade, considers the restoration of the instrumental case as a necessary category fulfilling the requirement of the grammatical norms of the language as an important issue (2006, p. 10).

Thus, our research on the XV century literary documents in the Azerbaijani-Turkic language makes it clear that even though the ancient instrumental case of noun could preserve its existence in the Azerbaijani literary language during the medieval period, -In, -in suffix had become already archaic during that period, possibly even earlier, and consequently could only be preserved in the structure of some lexical units in crystallised form. Such that, in the language of the literary documents from that period we can see stabilised words in the form of single units: dünün, yarın, sənsizin, ansızın, kışın, yazın, əvəlin, axırın, küzün, saqın, etc. Instrumental case expressed with birlə, bilə, ilə postpositions has already lost its case function and became stabilised in modern Azerbaijani language in the form of -la, -lə participation postpositions.

\section{Bibliography}

Alizade A. (2006). Once again on the instrumental-togetherness case of noun (comparative historical research). Turkology, № 1, 3-12.

Asker R. (2003). Qutadgu Bilig. Baku: Elm.

Dilaçar A. (1995). Kutadgu Bilig İncelemesi [Research on Kutadgu Bilig]. Ankara.

Donidze, G. (1955). Формы и значения творительного падеже в хакасском языка и литературы [Forms and meanings of the instrumental case in Khakass language and literature]. Abakan.

Dyrenkova, N. P. (1941). Грамматика шорского языка [Grammar of the Shor language]. Moscow.

Huseynzade M. (1983). Müasir Azərbaycan dili [Contemporary Azerbaijani language]. Baku: Maarif.

Kishvari. (1984). əsərləri [Works]. Baku: Yazichi.

Kishvari. (2010). Türk Divanı [Turkish Divan]. Baku: Nurlan.

Kitabi-Dədə Qorqud [Book of Dede Korkut]. (1988). Baku.

Mahmut of Kashgar. (1985). Divanu Lûgat-it-Turk. Translation. Vol I. Translator Besim Atalay. Ankara.

Mammadov, Y. (1979). Orxon-Yenisey abidələrində adlar [Names in Orkhon-Yenisey inscriptions]. Vol I. Baku.

Mansuroğlu, M. (1998). Karahanlıca, Tarihi Tükr Şiveleri [Karahanli language, Historical Turkic dialects]. Ankara.

Mirza Kazem-Bek. (1961). Обшая грамматика турецко-татарского языка [Common grammar of the Turkish-Tatar language]. Kazan.

Mirzazade, H. (1990). Azərbaycan dilinin tarixi qrammatikası [Historical grammar of the Azerbaijani language]. Baku: Azerbaijan University Press.

Musayev, K. (1961). Грамматика караимского языка [The grammar of the Karaim language]. Moscow.

Musayeva, A. (2003). Dədə Ömər Rövşəni əlyazmaları üzərində araşdırmalar [Research on manuscripts by Dada Omar Rovshani]. Vol I. Baku: Nurlan. 
Musayeva, A. (2012). Şeyx Ibrahim Gülşəni Bərdəi və Türk Divanı [Sheikh Ibrahim Gulsheni Bardai and the Turkish Divan]. Vol I. Baku: "Science and Education".

Nagisoylu, M. (2011). Şirazinin "Gülşəni-raz" tərcüməsi [Translation of Shirazi's "Gulshani Raz"]. Baku: "Science and Education".

Novruzov, M. (1987). Türk dillərində hal kateqoriyasının formalaşması və inkişafı (oğuz qrupu türk dillərinin materialları əsasında) [The formation and development of the case category in Turkic languages (based on materials of the Oguz group of Turkic languages)]. Baku: ND.

Pashali, A. (2011). əfsəhəddin Hidayət və "Divan"ı (tekstoloji-filoloji tədqiqat və mətn) [Efseheddin Hidayat and his "Divan" (textological-philological research and text)]. Baku: Nurlan.

Rajabli, A. (2002). Göytürk dilinin morfologiyası [Morphology of the Gokturk language]. Baku.

Rassadin V. М. (1978). Морфология тофалфрского языка в сравнительном освещении [Morphology of Tofalilar language in comparative analysis]. Moscow.

Seyidov, Y. (2000). Azərbaycan dilinin qrammatikası. Morfologiya [Grammar of the Azerbaijani language. Morphology]. Baku.

Shcherbak, A. М. (1961). Грамматический очерк языка тюркских текстов X-XIII вB. из Восточного Туркестана [Grammatical essay on the language of the Turkic texts of X-XIII centuries from East Turkestan]. Moscow-Leningrad.

Shukurlu, A. (1993). Qədim türk yazılı abidələrinin dili [Language of the ancient Turkic literary documents]. Baku: Maarif.

Shukurov, A. (1981). Azerbaycan dilinin tarixi qrammatikası [The historical grammar of the Azerbaijani language]. Baku: API.

Turkmen-Russian Dictionary. (1968). Moscow.

von Gabain, A. (1998). Eski Türkce, Tarihi Türk Şiveleri [Ancient Turkish, Historical Turkic dialects]. Ankara. 